\title{
STUDI KUALITATIF GANGGUAN PENDENGARAN AKIBAT BISING / NOISE INDUCED HEARING LOSS (NIHL) PADA MARSHALLER DI BANDAR UDARA SULTAN THAHA KOTA JAMBI TAHUN 2020
}

\author{
Qualitative Study of Noise Induced Hearing Loss on Marshaller at Sultan Thaha's \\ Airport Jambi City in 2020
}

Bella Armia Putri ${ }^{1}$, Rd. Halim ${ }^{1}$, Helmi Suryani Nasution ${ }^{1}$

${ }^{1}$ Program Studi Ilmu Kesehatan Masyarakat, Universitas Jambi

\begin{abstract}
Abstrak
Kebisingan merupakan salah satu sumber penyebab terjadinya gangguan pendengaran terhadap manusia. Bandar udara dapat menimbulkan kebisingan sebagai hasil dari pencemaran melalui aktivitas lalulintas penerbangan. Berdasarkan data yang diperoleh dari hasil pengukuran tingkat kebisingan dengan alat ukur sound level meter menunjukkan bahwa rata-rata tingkat kebisingan yang dihasilkan di area apron Bandar Udara Sultan Thaha Kota Jambi sebesar 91,4 dB. Tujuan dari penelitian ini untuk mengetahui gambaran gangguan pendengaran akibat bising pada marshaller di Bandar Udara Sultan Thaha Kota Jambi tahun 2020. Penelitian dilakukan dengan observasional menggunakan pendekatan deskriptif kualitatif. Dari hasil penelitian yang dilakukan, diperoleh 2 dari 3 marshaller yang merupakan informan utama dalam penelitian mengalami gangguan pendengaran. 1 dari 2 informan tersebut mengalami gangguan pendengaran akibat bising pada kedua telinganya, sedangkan informan lainnya mengalami gangguan pendengaran akibat bising di telinga sebelah kanan. Informan tidak mengalami gangguan pendengaran akibat bising (telinga normal). Pencegahan hanya dapat dilakukan melalui penggunaan alat pelindung diri terhadap pekerja tetapi masih kurangnya kedisiplinan dalam menerapakan penggunaan APD tersebut.
\end{abstract}

Kata Kunci: Bandar Udara, Gangguan Pendengaran, Kebisingan.

\begin{abstract}
Noise is one of the causes of noise induced hearing loss in humans. Airport can caused noise as the result of contamination through flight traffic activity. Based on data which obtained from measurement result of noise level using sound level meter, showed that average noise in apron of Sultan Thaha's Airport Jambi City equal to $91,4 \mathrm{~dB}$. The aim of this study is to find out an illustration of nose induced hearing loss on marshaller at Sultan Thaha's Airport Jambi City in 2020. The study is done through observating using descriptive approach. Based on the result of study obtained 2 of 3 marshallers are having hearing disorders. 1 of that 2 marshallers is having NIHL in both ears, while another marshaller is having NIHL only in right ear. Marshaller has no NIHL (normal ears). Prevention can only be done through personal protective equipment used to the worker, but still lack of discipline to use the equipment.
\end{abstract}

Keywords: Airport, NIHL, Noise.

Korespondensi : Bella Armia Putri

Email : armiabell@gmail.com 


\section{PENDAHULUAN}

World Health Organisation (WHO) tahun 2995, telah memperkirakan secara kasar bahwa sebanyak $2 \%$ dari populasi manusia di luar (berkisar 120 juta orang) telah memiliki permasalahan pendengaran ${ }^{1}$. Angka tersebut diperkirakan akan terus meningkat pada tahun 2003 dengan kisaran 240 juta populasi manusia di dunia, 78 juta orang diantaranya merupakan masyarakat yang berada di negara berkembang. Tidak hanya itu, WHO juga memperkirakan bahwa sekitar 10\% populasi di dunia terpapar bising yang berpotensi akan memberikan dampak berupa gangguan pendengaran ${ }^{2}$.

Global Burden Disease tahun 2010, menyatakan bahwa sekitar 1-3 milyar orang telah mengalami gangguan pendengaran akibat bising, dimana merupakan kasus yang menduduki peringkat ke-13 sebagai penyebab disabilitas $^{2}$. Sekitar $16 \%$ orang dewasa di dunia pada umumnya mengalami ketulian yang disebabkan akibat kerja, sehingga menyebabkan banyak negara yang ada di dunia menjadikan kasus gangguan pendengaran karena faktor bising atau yang biasa diketahui sebagai Noise Induced Hearing Loss (NIHL) sebagai penyakit akibat kerja yang harus diperhatikan ${ }^{3}$.

WHO, 2012 menunjukkan data prevalensi gangguan pendengaran yang ada di Asia Tenggara sebesar $27 \%$ atau berkisar 156 juta orang dari total populasi yang $\mathrm{ada}^{4}$. Sebanyak $9,3 \%$ atau sekitar 49 juta orang dengan golongan usia dibawah kurang dair 65 tahun mengalami gangguan pendengaran yang dikarenakan suara bising yang diproduksi dari lingkungan tempat mereka bekerja.

Hasil laporan oleh WHO tahun 2018 tentang ketulian dan gangguan pendengaran menyatakan bahwa sebanyak 1,1 milyar orang dengan rentang usia 12 hingga 35 tahun memiliki risiko kehilangan pendengaran mereka disebabkan oleh paparan kebisingan ${ }^{5}$. sedangkan berdasarkan Riset Kesehatan Dasar Republik Indonesia (Riskesdas RI) tahun 2013, menunjukkan hasil data prevalensi gangguan pendengaran secara nasional sebesar 2,6\% yang diakibatkan oleh paparan bising secara berlebiha di area tempat kerja ${ }^{6}$. Ketulian yang terjadi di Indonesia secara nasional mencapai 4,6\% di tahun 2007 dan terus meningkat tiap tahunnya hingga terjadi penurunan di tahun 2013 yakni sebesar 2,6\%. Walaupun demikian, diperkirakan angka tersebut akan terus meningkat tiap tahunnya seiring dengan perkembangan industri ${ }^{3}$.

Berdasarkan hasil data dari Komite Nasional Penanggulangan Gangguan Pendengaran dan Ketulian tahun 2014, menunjukkan hasl bahwa gangguan pendengaran akibat bising di Indonesia merupakan yang tertinggi se-Asia Tenggara dikarenakan mencapai $16,8 \%$ atau berkisar 36 juta orang dari total populasi ${ }^{4}$. Survei Multi Center di Asia Tenggara menunjukkan hasil bahwa Indonesia tergolong dalam 4 negara yang memiliki prevalensi ketulian yang cukup tinggi yakni sebesar $4,6 \%{ }^{7}$.

Gangguan pendengaran akibat bising diperoleh dari kondisi fisik yang ada di tempat kerja, yakni kebisingan yang melebihi Nilai Ambang Batas (NAB) yang telah ditetapkan. Salah satu tempat kerja yang dapat menimbulkan kebisingan adalah Bandar Udara. Bandar Udara, merupakan mediator sebagai penghubung antar pusat perekonomian, pusat pemerintahan, dan daerah wisata dengan menggunakan transportasi berupa pesawat terbang untuk menghubungkan antar tempat tersebut ${ }^{8}$.

Bandar Udara dapat menimbukan kebisingan sebagai hasil dari 
pencemaran melalui aktivitas lalu lintas penerbangan. Tingginya kebisingan di Bandar Udara dapat dipengaruhi oleh frekuensi jumlah penerbangan, jenis mesin pesawat, dan dimensi pesawat itu sendiri. Semakin besar dimensi pesawat, maka akan semakin besar pula mesin jet yang dibutuhkan oleh pesawat tersebut sehingga akan menghasilkan tingkat kebisingan yang semakin besar pula.

Pekerja ground handling, khususnya marshaller, merupakan pekerjaan yang memiliki potensi terpapar bising yang cukup tinggi dan berisiko mengalami gangguan pendengaran akibat bising tersebut. Bandar Udara merupakan tempat dimana marshaller bekerja sebagai petugas parkir pesawat dimana berhadpaan secara langsung dengan mesi pesawat yang masih dalam kondisi menyala. Marshaller melakukan operasional terhadap pesawat ketika pemarkiran di sekitar leingkungan Bandar Udara, yang merupakan komponen terpapar oleh bising. Dengan tingkat kebisingan yang tinggi dan terus-menerus serta dipaksanakan, maka akan menyebabkan gangguan pendengaran bagi marshaller. Gangguan yang tidak dapat dicegah ataupun diatasi berpotensi menimbulkan kecelakaan kerja pada pekerja itu sendiri.

Hasil penelitian yang pernah dilakukan di Sudan memperoleh hasil sebesar 55,5\% pekerja di Bandar Udara Internasional Khartoum terpapar faktor bising dengan intensitas melebihi $85 \mathrm{~dB}$ dimana pekerja ground handling terpapar bising sebesar $93 \mathrm{~dB}$. Tidak hanya itu, hasil penelitian di salah satu Bandar Udara yang ada di Karachi, Pakistan juga menunjukkan hasil bahwa pekerja yang terpapar bising dari pesawat mengalami gangguan pendengaran dengan golongan derajat ringan sebesar $16,9 \%$, sedang $22,9 \%$, dan berat $15,3 \%^{2}$. Owen (1975) juga menyatakan jika kebisingan yang ditimbulkan dari mesin pesawat yang melakukan aktivitas berupa landing maupun take off berkisar antara $110 \mathrm{~dB}$ hingga $120 \mathrm{~dB}$. Berdasarkan data hasil pemantauan kebisingan yang dilakukan di 18 Bandar Udara di Indonesia tahun 2003 dan 2004, menunjukkan bahwa tingkat kebisingan diatas Nilai Ambang Batas (NAB), yaitu sebesar $90 \mathrm{~dB}^{9}$.

PT. Angkasa Pura II (Persero), merupakan salah satu Badan Usaha Milik Negara (BUMN) yang ditugaskan oleh Pemerintah untuk memberikan pelayanan kebandarudaraan di Indonesia bagian barat. Terdapat tiga Bandar Udara yang ada di Provinsi Jambi, yakni Bandar Udara Sultan Thaha yang terletak di Kota Jambi, Bandar Udara Muara Bungo yang terletak di Bungo, dan Bandar Udara Depati Parbo yang terletak di Kerinci. Bandar Udara Sultan Thaha merupakan Bandar Udara yang memiliki satu landasan pacu dengan dimensi seluas 2.220 meter $\mathrm{x} 45$ meter, dan melayani sektiar 40 penerbangan dalam satu hari dengan destinasi ke beberapa kota yang terdapat di Indonesia.

Sedangkan data yang diperoleh berdasarkan hasil pengukuran tingkat kebisingan dengan alat ukur sound level meter menunjukkan bahwa rata-rata tingkat kebisingan yang dihasilkan di area Apron Bandar Udara Sultan Thaha Kota Jambi sebesar 91,4 dB. Tingginya tingkat kebisingan yang melebihi Nilai Ambang Batas (NAB) telah ditetapkan oleh Peraturan Menteri Tenaga Kerja dan Transmigrasi (Permenakertrans) Nomor PER.13/MEN/X/2011 tentang Nilai Ambang Batas Faktor Fisika dan Faktor Kimia di Tempat Kerja Pasal 5(1) yang berbunyi "NAB kebisingan ditetapkan sebesar 85 decibel A (dBA)" 
Dengan kasus gangguan pendengaran akibat bising bagi pekerja yang cukup tinggi inilah sehingga membuat peneliti tertarik untuk melakukan penelitian tentang analisis hubungan paparan kebisingan dengan kejadian gangguan pendengaran akibat bising / Noise Induced Hearing Loss (NIHL) pada marshaller di Bandar Udara Sultan Thaha Kota Jambi tahun 2020.

\section{METODE}

Penelitian yang dilakukan merupakan penelitian observasional dengan menggunakan pendekatan deskriptif kualitatif dimana bertujuan untuk menggambarkan variabel yang disajikan. Variabel dalam penelitian ini merupakan intensitas bising, lama paparan, jarak, penggunaan alat pelindung telinga, dan NIHL. Penelitian dilakukan di Bandara Sultan Thaha Kota Jambi pada bulan FebruariDesember 2020. Informan utama adalah 3 orang marshaller yang bekerja dari PT. PTN dan PT. Gapura. Informan pendukung terdiri dari 1 orang airside leader, 1 orang loading master, 1 orang safety officer, dan 1 orang manajer AMC.

Metode pengumpulan data menggunakan teknik observasi pasif dan umum, wawancara terstruktur, semi terstruktur, dan tidak terstruktur.
Tahapan analisis data reduksi data, penyajian data, dan penarikan kesimpulan. Untuk menjaga keabsahan data dilakukan triangulasi sumber. Penelitian yang dihasilkan akan disesuaikan dengan standard dan peraturan yang berlaku terkait gangguan pendengaran akibat bising / Noise Induced Hearing Loss (NIHL) pada marshaller di Bandar Udara Sultan Thaha Kota Jambi tahun 2020.

\section{HASIL PENELITIAN}

PT. Angkasa Pura II Bandar Udara Sultan Thaha merupakan salah satu Badan Usaha Milik Negara (BUMN) di Kota Jambi yang bergerak dalam bidang usaha pelayanan jasa kebandarudaraan dan pelayanan jasa terkait bandar udara dengan pengoptimalan dalam pemberdayaan potensi sumber daya yang dimiliki serta penerapan praktik tata kelola perusahaan yang baik. Bandar Udara Sultan Thaha Kota Jambi merupakan salah satu dari 19 bandar udara yang dikelola oleh PT. Angkasa Pura II.

Informan utama dalam penelitian ini adalah marshaller yang bertugas untuk menuntun pesawat ketika mendarat (landing) sehingga berada pada posisi yang tepat. Berikut karakteristik informan utama :

Tabel 1. Karakteristik Informan Utama

\begin{tabular}{|c|c|c|c|c|c|c|}
\hline Nama & Usia & $\begin{array}{c}\text { Jenis } \\
\text { Kelamin }\end{array}$ & $\begin{array}{c}\text { Pendidikan } \\
\text { Terakhir }\end{array}$ & Jabatan & Instansi & $\begin{array}{c}\text { Lama } \\
\text { Kerja }\end{array}$ \\
\hline MA & 28 Tahun & Laki-Laki & SMA & Marshaller & PT.PTN & 9 Tahun \\
\hline SP & 52 Tahun & Laki-Laki & SMP & Marshaller & PT.GAPURA & 20 Tahun \\
\hline FA & 21 Tahun & Laki-Laki & SMA & Marshaller & PT.GAPURA & 3 Tahun \\
\hline
\end{tabular}

Informan pendukung pada penelitian ini adalah Manager divisi Aircraft Movement Controller, Officer Safety Risk and Quality Control dari
PT. Angkasa Pura II Bandar Udara Sultan Thaha, Perwakilan Pimpinan PT. PTN, Perwakilan Pimpinan PT. GAPURA. 
Tabel 2. Karakteristik Informan Pendukung

\begin{tabular}{|c|c|c|c|c|c|c|}
\hline Nama & Usia & $\begin{array}{c}\text { Jenis } \\
\text { Kelamin }\end{array}$ & $\begin{array}{c}\text { Pendidikan } \\
\text { Terakhir }\end{array}$ & Jabatan & Instansi & $\begin{array}{c}\text { Lama } \\
\text { Kerja }\end{array}$ \\
\hline RA & 27 Tahun & Laki-Laki & S1 & $\begin{array}{c}\text { Safety } \\
\text { Officer }\end{array}$ & PT.AP II & 7 Tahun \\
\hline PPN & 32 Tahun & Laki-Laki & S1 & $\begin{array}{c}\text { Manager } \\
\text { AMC }\end{array}$ & PT.AP II & 7 Tahun \\
\hline DP & 45 & Laki-Laki & SMA & $\begin{array}{c}\text { Airside } \\
\text { Leader }\end{array}$ & PT.PTN & 12 Tahun \\
\hline JS & 41 & Laki-Laki & SMA & $\begin{array}{c}\text { Loading } \\
\text { Master }\end{array}$ & PT.GAPURA & 10 Tahun \\
\hline BVL & 22 Tahun & Laki-Laki & SMA & Marshaller & PT.PTN & 4 Tahun \\
\hline YSR & 20 Tahun & Laki-Laki & SMA & Marshaller & PT.GAPURA & 4 Tahun \\
\hline
\end{tabular}

Penelitian pengambilan data kebisingan dilakukan di wilayah apron Bandar Udara Sultan Thaha Kota Jambi. Apron merupakan salah satu bagian dari wilayah kawasan yang ada di bandar udara yang berfungsi sebagai tempat untuk pemarkiran pesawat terbang. Kebisingan yang bersumber dari mesin pesawat yang masih aktif terdengar sangat berisik di wilayah apron ini.

Perusahaan penerbangan pesawat yang memasuki apron Bandar Udara Sultan Thaha Kota Jambi adalah Garuda Indonesia Airline, Citilink, Lion Air, Sriwijaya, Batik Air, dan Wings Air. Pegawai yang melaksanakan tugas untuk memarkirkan pesawat ke posisi yang tepat disebut sebagai marshaller. Marshaller yang bekerja di Bandar Udara Sultan Thaha Kota Jambi terdiri atas 2 perusahaan, yaitu PT. Gapura Indonesia (PT. GAPURA) dan PT. Prathita Titian Nusantara (PT. PTN). Marshaller dari PT GAPURA hanya meng-handle pesawat yang berasal dari perusahaan penerbangan Garuda Indonesia Airlines dan Citilink. Sedangkan marshaller dari PT. PTN hanya meng-handle pesawat yang berasal dari perusahaan penerbangan Lion Air, Sriwijaya, Batik Air, dan Wings Air.

Tabel 3. Data Intensitas Kebisingan dalam satu hari

\begin{tabular}{|c|l|c|c|c|c|}
\hline NO & \multicolumn{1}{|c|}{ AIRLINE } & $\begin{array}{c}\text { LANDING } \\
\text { TIME }\end{array}$ & PT & $\begin{array}{c}\text { BISING } \\
\text { (dBA) }\end{array}$ & \multicolumn{2}{|c|}{ APD } \\
\hline 1 & Lion Air & $06: 20$ & PTN & 89.11 & $\sqrt{ }$ \\
\hline 2 & Citilink & $06: 40$ & GAPURA & 89.675 & $\sqrt{ }$ \\
\hline 3 & Garuda Indonesia & $06: 57$ & GAPURA & 94.67 & $\sqrt{ }$ \\
\hline 4 & Wings Air & $08: 30$ & PTN & 91.4 & $\sqrt{ }$ \\
\hline 5 & Wings Air & $09: 00$ & PTN & 91.15 & $\sqrt{ }$ \\
\hline 6 & Lion Air & $09: 10$ & PTN & 87.13 & $\sqrt{ }$ \\
\hline 7 & Garuda Indonesia & $09: 45$ & GAPURA & 92.3 & $\sqrt{ }$ \\
\hline 8 & Garuda Indonesia & $10: 30$ & GAPURA & 94.16 & $\sqrt{ }$ \\
\hline
\end{tabular}




\begin{tabular}{|c|l|c|c|c|c|}
\hline 9 & Citilink & $12: 15$ & GAPURA & 88.13 & $\sqrt{ }$ \\
\hline 10 & Wings Air & $12: 50$ & PTN & 91.05 & $\sqrt{ }$ \\
\hline 11 & Batik Air & $12: 55$ & PTN & 95.6 & $\sqrt{ }$ \\
\hline 12 & Lion Air & $13: 10$ & PTN & 90.467 & $\sqrt{ }$ \\
\hline 13 & Sriwijaya Air & $14: 30$ & PTN & 91.25 & $\sqrt{ }$ \\
\hline 14 & Wings Air & $14: 45$ & PTN & 93.975 & $\sqrt{ }$ \\
\hline 15 & Garuda Indonesia & $16: 50$ & GAPURA & 92.85 & X \\
\hline 16 & Wings Air & $18: 15$ & PTN & 92.475 & $\sqrt{ }$ \\
\hline 17 & Wings Air & $18: 20$ & PTN & 91.6 & $\sqrt{ }$ \\
\hline 18 & Lion Air & $18: 25$ & PTN & 91.225 & $\sqrt{ }$ \\
\hline 19 & Wings Air & $19: 05$ & PTN & 91.72 & $\sqrt{ }$ \\
\hline 20 & Citilink & $19: 05$ & GAPURA & 89.267 & X \\
\hline 21 & Lion Air & $20: 40$ & PTN & 88.605 & $\sqrt{ }$ \\
\hline
\end{tabular}

Menurut informan pendukung yang bekerja sebagai officer di unit safety menyatakan bahwa kebisingan yang ada di wilayah sisi udara (apron) bersumber dari engine pesawat yang sedang melakukan aktivitasnya baik take off maupun landing. Berikut kutipannya :

- “...Sumber kalau untuk di sisi udara itu hanya dari engine pesawat udara. Karena, terkait biasanya di ruang jenset itu tidak di sisi udara. Itu lebih ke teman-teman teknik. Kalau untuk sisi udara lebih ke pesawat udara. Kalau untuk prosesnya memang mesin pesawat tersebut mengganggu, apalagi masuk ke apron masih dalam posisi middle thrush engine. Jadi suara bisingnya masih ada. Maka dari itu, pasti sangat mengganggu untuk kebisingan pekerja di sisi udara ketika engine nya hidup." (RA, PT. AP II, 27 tahun).

Dua orang informan utama merasa kebisingan yang ditimbulkan dari engine pesawat mengganggu mereka ketika bekerja. Berikut kutipannya :
-“...Ya tetap terganggu karena memang ruang lingkupnya bising. Ada pesawat yang bising ringan, bising sedang, dan bising berat gitu. Misalkan model lama pada engine sriwijaya kan engine nya panjang, itu sangat bising. Misalkan mau terbang nih, bisingnya bisa sampai sini." (MA, PT. PTN, 28 tahun).

-“...Terganggu lah, ketika komunikasi dengan teman yang lain. Seperti kita mau suruh dia kesana misalnya kan, kita lagi mengerjakan ini, kita suruh dia mengerjakan yang itu kan tidak mungkin kita jerit keras-keras. Pasti tidak akan dengar. Itulah terganggunya. Terus itu di telinga juga apa sih nih, pesawat berisik kali gitu kan." (FA, PT. GPAURA, 21 tahun).

Berdasarkan hasil wawancara dengan 3 marshaller sebagai informan utama dalam penelitian ini, marshaller dari pihak PT. PTN memiliki schedule on duty yang berbeda dengan marshaller dari pihak PT. GAPURA dalam satu minggu. Berikut kutipannya 
-“...Itu menyesuaikan lagi dengan jumlah flight operate dan personilnya. Misalkan seperti sekarang dengan kondisi covid19, jadi tidak terlalu banyak jumlah flight operatenya dalam sehari, jadi bisa schedule 6 hari kerja dan 1 hari libur." (MA, PT. PTN, 28 tahun).

- “...Dia kalau sekarang itu 3-1, 3 hari kerja 1 hari libur. Kalau dulu masih 4-1." (FA, PT. GAPURA, 21 tahun).

Berdasarkan hasil dari wawancara dengan 3 marshaller sebagai informan utama dalam penelitian ini, seluruhnya menyatakan bahwa mereka merasa tidak bermasalah dengan jarak mereka bekerja terhadap pesawat. Berikut kutipannya :

- “...Kalau kita pakai pelindung pendengaran memang sudah standarnya segitu, sekitar antara 20 meteran lah. 15 sampai 20 meter. Cuman kalau 25, istilahnya kalau kita kurang yakin, lebih baik agak dekat. Jadi tidak masalah." (MA, PT.PTN, 28 tahun).

- “...Rasanya nyaman.

Masalahnya jauh juga sih berapa meter itu, sekitar 7 atau 8 lah." (SP, PT. GAPURA, 52 tahun).

-“...Aman. Karena posisinya pas mungkin. Pilot lihat kita, kita lihat pilot, sudah beres." (FA, PT. GAPURA, 21 tahun).

Dari hasil wawancara yang telah dilakukan oleh ketiga informan utama, diperoleh kesimpulan bahwa mereka merasa kurang nyaman dalam menggunakan alat pelindung telinga baik itu ear plug maupun ear muff yang disediakan oleh perusahaan. Berikut kutipannya :
- “...Ear plug enggak nyaman kalau kelamaan dipakai saja. Tapi kalau sudah biasa tidak masalah. Dia kan menyumbat disini kan, jadi ya mungkin peredaran kurang lancar. Kalau saya pakai itu sekitar 5 sampai 10 menitan lah. Kalau kelamaan ya ada terasa ngilu." (MA, PT. PTN, 28 tahun).

- “...Gatal kalau pakai ear plug dimasukkin terlalu dalam, geli rasanya. Kalau ear muff kadang-kadang kalau terlalu nekan pusing dia." (SP, PT. GAPURA, 52 tahun).

- “...Risih itu ada, karena tekanan kalau pakai ear muff itu kan semakin ditekan kepalanya. Lebih enak pakai ear plug kalau dari segi tidak ribetnya. Kalau dari segi safetynya itu lebih bagus itu pakai ear muff. Kalau saya personal lebih nyaman pakai ear plug. Tapi kadang apasih gitu, risih." (FA, PT. PTN, 21 tahun).

PTN menyediakan ear plug tipe banded plug sedangkan PT. GAPURA menyediakan ear plug tipe multiple use.

Dari hasil wawancara dengan informan utama dalam penelitian ini diperoleh bahwa seluruhnya belum pernah melakukan pengecekan kesehatan pendengaran (tes audiometri), tetapi 2 dari 3 responden mengaku hanya melakukan cek kesehatan umum. Berikut kutipannya :

-“...Belum pernah cek kesehatan telinga. Waktu pertama pengrekrutan itu ada surat di cek darah, buta warna, dan tensi gitu." (FA, PT. GAPURA, 21 tahun).

- “...Tidak ada. Saya belum pernah cek kesehatan khusus telinga." (SP, PT. GAPURA, 52 tahun). 
- “...Ya saya kalau rutinan ikut program bandara seperti pengecekan tahunan. Ketika menjelang lebaran atau tahun baru, biasanya ada kegiatan untuk check up seperti tekanan darah, hemoglobin, kolesterol, asam urat, dan lain-lain. Kalau khusus untuk telinga belum pernah." (MA, PT. PTN, 28 tahun).

\section{PEMBAHASAN}

Penyakit akibat kerja merupakan suatu kondisi individu dimana mengalami gangguan kesehatan yang disebabkan karena baik dari kegiatan kesehariannya maupun zat tertentu yang ada di tempat kerjanya. Terdapat banyak jenis pada penyakit akibat kerja dimana memiliki pemicu ataupun penyebab yang berbeda pada setiap jenisnya. Gangguan pendengaran akibat bising atau noise induced hearing loss (NIHL) merupakan salah satu penyakit akibat kerja yang disebabkan oleh kebisingan. Seseorang yang bekerja di lingkungan kerja dengan intensitas kebisingan yang tinggi dalam jangka waktu yang lama berpotensi mengalami gangguan pendengaran akibat bising. Tidak hanya itu, lama paparan individu terhadap kebisingan, jarak dengan sumber bising, dan penggunaan alat pelindung telinga merupakan faktor pemicu seseorang terkena gangguan pendengaran akibat bising tersebut ${ }^{16}$.

Kebisingan yang ada di wilayah tempat kerja sisi udara bersumber dar mesin pesawat yang dioperasikan oleh airlines. Tipe pesawat yang dioperasikan di Bandar Udara Sultan Thaha Kota Jambi yaitu Boeing 737500, Boeing 737-800NG, Boeing 737900ER, Airbus 320, dan ATR 72-600. Kebisingan yang dihasilkan oleh engine pesawat tersebut dapat melebihi $85 \mathrm{~dB}$, yang mana melebihi nilai ambang batas yang telah ditetapkan oleh pemerintahan. Dalam satu hari, kebisingan yang ada di sisi udara Bandar Udara Sultan Thaha Kota Jambi mampu mencapai 91.4 dB. Kondisi tersebut juga terjadi di sisi udara pada beberapa bandar udara yang ada di Indonesia seperti bising di apron Bandar Udara I Gusti mencapai $92.1 \mathrm{~dB}$. Hal tersebut juga terjadi dalam penelitian yang dilakukan di apron bandar udara di Karachi Pakistan mencapai kebisingan hingga $110 \mathrm{~dB}^{22}$.

Berdasarkan pemeriksaan medical check up audiometri test yang dilakukan terhadap ketiga informan utama, diperoleh hasil satu diantaranya mengalami noise induced hearing loss berat pada kedua telinganya. Hal tersebut disebabkan karena terpaparnya informan tersebut oleh kebisingan yang ada di lingkungan tempat kerja yang bersumber dari engine pesawat. Hal ini sejalan dengan penelitian yang dilakukan oleh Alrahman Joneri (2013). Hal ini sesuai dengan teori yang menyatakan bahwa pekerja yang melakukan pekerjaan di tempat kerja yang memiliki paparan intensitas kebisingan yang tinggi akan rentan mengalami gangguan pada indera pendengarannya ${ }^{24}$. Gangguan pendengaran tersebut disebabkan karena rusaknya pada sel rambut luar yang ada di organ corti telinga.

Walaupun begitu, setiap informan memiliki kasus noise induced hearing loss yang berbeda-beda. Dimana salah satu informan utama mengalami gangguan pendengaran hanya pada telinga kanannya, sedangkan informan lainnya sama sekali tidak mengalami gangguan pendengaran (telinga normal). Perbedaan hasil dari medical check up yang dilakukan dapat terjadi meskipun informan bekerja dengan paparan bising berintensitas tinggi setiap harinya. Hal ini dapat disebabkan karena berbagai 
faktor baik internal seperti kesensitifitas telinga setiap individu yang berbeda maupun faktor eksternal seperti penggunaan alat pelindung telinga. Hal ini serupa dengan penelitian yang dilakukan oleh Pragtignyowati dimana di tempat kerja dengan kebisingan lebih dari $85 \mathrm{~dB}$ terdapat $72,2 \%$ karyawan tidak mengalami noise induced hearing loss sedangkan 27,8\% karyawan mengalami noise induced hearing $\operatorname{loss}^{25}$.

Dari penelitian yang dilakukan, diperoleh informasi bahwa 2 marshaller bekerja dengan masa kurang dari 10 tahun, dan 1 orang informan telah bekerja dengan masa lebih dari 10 tahun. Dimana pada setiap instansi memiliki jam operasional kerja yang berbeda. Dalam penanganan K3 secara administrasi, yakni jam operasional kerja yang dilaksanakan oleh pihak PT. GAPURA lebih tersusun dibandingkan PT. PTN, dimana diketahui bahwa marshaller dari instansi PT. GAPURA memiliki jadwal 3 hari kerja dan 1 hari libur beserta shiftnya, sedangkan jadwal marshaller dari PT. PTN bekerja tergantung pada jam penerbangan yang ada sehingga tidak menentu.

Di samping itu, jumlah penerbangan pesawat yang harus dihandle oleh PT. PTN lebih banyak daripada PT. GAPURA. Hal tersebut dikarenakan PT. PTN harus menghandle pesawat yang beroperasi dari airline Lion Air, Batik Air, Sriwijaya Air, dan Wings Air. Sedangkan PT. GAPURA hanya meng-handle pesawat yang beroperasi dari airline Garuda Indonesia dan Citilink. Jumlah tersebut mempengaruhi lama paparan seorang marshaller untuk terpapar oleh kebisingan dalam hitungan satu hari.

Berdasarkan hasil observasi, pelaksanaan pemarkiran pesawat yang dilakukan oleh marshaller hanya berlangsung selama 15-20 menit hingga pesawat berada pada stop line. Akan tetapi, tugas yang harus dilaksanakan oleh marshaller tidak hanya sebatas memarkirkan pesawat, tetapi ia juga merangkap membantu karyawan ground handling lainnya seperti mengurus kargo. Hal tersebut dapat memakan waktu 1 jam lebih. Dalam satu hari penuh marshaller tidak terpapar seutuhnya dengan kebisingan yang ditimbulkan oleh mesin pesawat. Sehingga dapat diperhitungkan lama paparan marshaller terpapar bising adalah jumlah aktivitas penerbangan dalam satu hari dikali 1 jam.

Meskipun begitu, berdasarkan hasil dari medical check up yang dilakukan menunjukkan bahwa informan dari PT. GAPURA yang mengalami NIHL merupakan karyawan yang baru bekerja selama 3 tahun dan meng-handle 4-5 pesawat dalam satu hari. Namun informan dari PT. PTN yang telah bekerja sekitar 9 tahun dengan jumlah penerbangan sekitar 15 penerbangan dalam satu hari tidak mengalami noise induced hearing loss atau dapat dikatakan kondisi telinga masih normal. Hal ini serupa dengan penelitian yang dilakukan oleh Pratignyowati ${ }^{25}$. Hal tersebut disebabkan karena setiap karyawan tidak terpapar oleh intensitas kebisingan yang sama besar. Akan tetapi teori Evenson (2012) dijelaskan bahwa semakin lama seseorang terpapar kebisingan dalam satu hari, maka akan semakin tinggi pula probabilitas orang tersebut untuk mengalami noise induced hearing loss. Karyawan yang bekerja di lingkungan tempat kerja yang bising selama lebih dari 10 tahun tetap memiliki kemungkinan tidak mengalami noise induced hearing loss ${ }^{3}$.

Jarak dari marshaller berdiri atau yang dikenal sebagai marshaller stop line berjarak 6.0 meter dari nose wheel position sebagaimana yang tertera pada Peraturan Direktur Jenderal 
Perhubungan Udara Nomor KP 39 Tahun 2015 tentang Standar Teknis dan Operasi Peraturan Keselamatan Penerbangan Sipil - Bagian 139 (Manual of Standard Casr - Part 139) Volume I Bandar Udara (Aerodromes). Namun pada pengaplikasiannya di lapangan, marshaller tidak benar-benar berdiri pada stop line position yang ada, dikarenakan menyesuaikan dengan ukuran pesawat dengan tujuan agar pilot dapat melihat marshaller memarkirkan pesawat ke posisi yang benar ${ }^{23}$.

Jarak individu dari sumber bunyi merupakan salah satu faktor yang dapat menimbulkan perbedaan intensitas kebisingan yang diperoleh. Hal ini disebabkan karena gelombang bunyi yang ditimbulkan merambat melalui udara dan akan mengalami suatu gesekan dengan udara, sehingga terjadi penurunan intensitas pada bising tersebut. Berdasarkan hasil observasi terhadap marshaller ketika melakukan pekerjaannya di lapangan, tidak dapat ditentukan seberapa jauh antara marshaller dengan engine pesawat yang merupakan sumber dari kebisingan yang ada. Hal ini disebabkan karena perbedaan pada ukuran atau panjang badan pesawat serta peletakkan engine tersebut di pesawat sehingga tidak dapat dipastikan berapa meter jarak antara marshaller dari sumber bising.

Tetapi apabila dibandingkan dengan hasil data dari pelaksanaan medical check up audiometri test yang dilakukan terhadap ketiga marshaller yang merupakan informan utama dalam penelitian ini, dapat ditarik kesimpulan satu dari tiga informan utama mengalami noise induced hearing loss. Hal ini disebabkan karena engine pada pesawat yang di-handle menimbulkan kebisingan yang tinggi walaupun berada di posisi yang cukup jauh dari marshaller itu sendiri.
Paparan kebisingan dengan intensitas yang tinggi di lingkungan tempat kerja mungkin tidak dapat dihindari oleh pekerja yang berada di lingkungan sekitarnya, salah satunya yaitu sisi udara bandar udara. Akan tetapi, risiko gangguan pendengaran akibat bising dapat dicegah secara optimal baik melalui pengendalian engineering atau rekayasa teknik dan penggunaan alat pelindung telinga dalam upaya terakhir terhadap pengendalian risiko kebisingan yang ada di tempat kerja.

Alat pelindung telinga baik ear plug maupun ear muff memiliki manfaat untuk mengurangi tingkat kebisingan yang dipaparkan dan mencegah pekerja dari risiko gangguan pendengaran akibat bising atau Noise Induced Hearing Loss (NIHL). Akan tetapi, tidak semua bahan pada alat pelindung telinga dapat meredam kebisingan dengan sama. Oleh karena itu perlu diketahui efektivitas dan kemampuan alat pelindung telinga dalam upaya mengurangi kebisingan yang ada melalui Noise Reduction Rating $(\mathrm{NRR})^{24}$.

Alat pelindung telinga yang disediakan oleh kedua instansi baik PT. PTN maupun PT. GAPURA merupakan ear plug yang diganti secara berkala setiap tahunnya. Ear plug tersebut diberikan ke setiap individu baik marshaller maupun karyawan lainnya yang berada di sisi udara ketika bekerja. Dalam upaya memastikan ear plug yang telah diberikan oleh perusahaan masingmasing, maka terdapat langkah-langkah dalam penggunaannya yang harus diperhatikan. PT.

Ear plug yang sudah terpasang dengan baik dan benar seharusnya dapat meredam intensitas kebisingan dengan optimal pula. Sehingga apabila seorang individu yang bekerja di lingkungan kerja yang bising menutup telinga dan 
melepasnya, maka seharusnya tidak terdapat perbedaan tingkat kebisingan yang signifikan. Dari hasil observasi dan wawancara dapat disimpulkan bahwa marshaller yang bekerja di sisi udara bandar udara masih belum menggunakan alat pelindung telinga dengan baik dan benar sesuai prosedur, yang mana mereka hanya memasang alat tersebut ala kadarnya, tidak menutup saluran pendengaran secara menyeluruh. Hal tersebut disebabkan karena marshaller merasa terganggu dan tidak nyaman ketika menggunakan alat pelindung telinga ketika bekerja.

Tidak hanya karena cara penggunaan alat pelindung baik yang kurang benar dan rasa tidak nyaman yang ditimbulkan ketika penggunaan alat tersebut, tetapi tidak adanya penyediaan ulang alat pelindung telinga oleh pihak perusahaan kepada marshaller apabila alat tersebut hilang ataupun rusak hingga jadwal pembaharuan berikutnya sesuai yang telah ditetapkan. Kurang tegasnya peraturan untuk pendisiplinan marshaller dalam penggunaan alat pelindung telinga juga mempengaruhi kebiasaan mereka, terutama bagi pihak PT. GAPURA.

Apabila dibandingkan antara PT. PTN dan PT. GAPURA, meskipun PT. PTN memiliki jadwal penerbangan yang lebih banyak dibandingkan dengan PT. GAPURA, dan jumlah karyawan PT. PTN yang lebih sedikit daripada PT. GAPURA, serta jadwal jam kerja PT. PTN yang lebih padat dibandingkan PT. GAPURA, akan tetapi marshaller dari PT. PTN sudah menjadikan penggunaan alat pelindung diri sebagai suatu kebiasaan. Di samping itu, salah satu marshaller dari PT. PTN melakukan teknik baru dalam menggunakan ear plug dengan tujuan semakin mereduksi intensitas kebisingan yang ada di lingkungan tempat kerjanya, yaitu melalui membasahi area karet ear plug yang akan dimasukkan ke lubang telinga.

Menurut Bogoch, pekerja yang tidak menggunakan alat pelindung telinga tersebut disebabkan oleh ketidaknyamanan yang dirasakan sewaktu dalam penggunaannya, kurangnya kepedulian antar rekan kerja, desain alat pelindung telinga yang cukup membuat pemakainya merasa terganggu pada proses berlangsungnya pekerjaan, dan minimnya wawasan mengenai gangguan pendengaran akibat bising $^{26}$.

Hasil dari medical check up audiometri test menunjukkan bahwa terdapat informan yang mengalami noise induced hearing loss akibat penggunaan alat pelindung telinga yang tidak disiplin dan cara penggunaannya yang kurang tepat. Kondisi ini serupa dengan penelitian yang dilakukan di Amerika, dimana terdapat hubungan yang signifikan antara penggunaan alat pelindung telinga oleh pekerja konstruksi dengan kejadian noise induced hearing loss ${ }^{3}$. Kurangnya rasa nyaman atau adanya rasa menganggu yang ditimbulkan ketika pemakaian alat pelindung telinga merupakan salah satu alasan penyebab marshaller tidak menggunakannya ketika sedang bekerja. Hal tersebut sesuai dengan penelitian yang pernah dilakukan oleh Pramana $(2015)^{3}$.

\section{KESIMPULAN DAN SARAN}

Kebisingan yang ada di lingkungan apron Bandar Udara Sultan Thaha Kota Jambi melebihi Nilai Ambang Batas (NAB) yang telah diatur, yakni sebesar 94,1 dB dalam satu hari. Lama marshaller yang bertugas memarkirkan pesawat di area apron Bandar Udara Sultan Thaha Kota Jambi melanggar peraturan yang telah ditetapkan oleh pemerintah. Jarak dari marshaller 
berdiri sampai engine pesawat berbedabeda. Dalam penerapannya, alat pelindung telinga belum digunakan sesuai prosedur oleh marshaller.

Diharapkan bagi Bandar Udara Sultan Thaha Kota Jambi untuk membantu dalam pengadaan medical check up audiometri test secara berkala enam bulan sekali atau menyesuaikan dengan Unit AMC PT. Angkasa Pura II Bandar Udara Sultan Thaha Kota Jambi sesuai dengan syarat dan ketentuan sehingga sesuai dengan Peraturan Menteri Tenaga Kerja dan Transmigrasi No. 13 Tahun 2011. Tidak hanya itu, diharapkan pihak Bandar Udara Sultan Thaha Kota Jambi untuk memfasilitasi pengadaan training $\mathrm{K} 3$ terhadap marshaller untuk PT. PTN dan PT. GAPURA dengan tujuan meningkatkan kesadaran pekerja itu. Serta pemasangan noise warning sign di area airside, dimana pekerja dilarang berada di area tersebut apabila tidak menggunakan alat pelindung telinga.

\section{DAFTAR PUSTAKA}

1. Dewi YA, Agustian RA. Skrining Gangguan Dengar pada Pekerja Salah Satu Pabrik Tekstil di Bandung. 2004;44(2):96-100.

2. Putri PDA, Setiawan EP, Ratnawati LM, Sutanegara SWD. Gambaran Ambang Dengar pada Petugas Parkir Pesawat (Marshaller) di PT. Gapura Angkasa Pura Bandar Udara Internasional I Gusti Ngurah Rai Tahun 2015. 2015.

3. Syah PB, Soedjajadi K. Pengaruh Penggunaan Pelindung Telinga dan Earphone terhadap Noise Induced Hearing Loss dan Tinitus pada Pekerja Bengkel. J Kesehat Lingkung. 2017;9(1):21-30.

4. Septiana NR, Widowati E. Gangguan Pendengaran Akibat
Bising. Higeia J Public Heal Res Dev [Internet]. 2017;1(1):73-82. Available from: http://journal.unnes.ac.id/sju/inde x.php/higeia

5. Nurfitriyana, Ivone J, Adhy P. Influencing Factors of Hearing Disorder in Helicopter and Casa Pilots. J Med Heal. 2020;2(5):22-30.

6. Ramadhani S, Silaban G, Hasan W. Pemakaian APT dengan Gangguan Pendengaran Pekerja Ground Handling di Bandara Kualanamu. J Kesehat Masy Andalas. 2017;12(32):3-9.

7. Choirunisa R. Gangguan Pendengaran dan Kesehatan Teknisi Skadron Udara 3 Lanud Iswahjudi serta Hubungannya dengan Tingkat Kebisingan. J Kesehat Lingkung. 2019;11(1):61-8.

8. Aldian F, Fachrul MF, Suswantoro E. Tingkat Kebisingan Pesawat Udara di Sekitar Bandara Udara Sultan Thaha, Jambi, Provinsi Jambi. 2018;259-65.

9. Depkes R. Profil PPM-PL [Internet]. 2004. Available from: http://bankdata.depkes.go.id

10. Ramita N, Laksmono R. Pengaruh Kebisingan dari Aktifitas Bandara Internasional Juanda Surabaya. J Ilm Tek Lingkung. 2015;4(1):19-26.

11. Keputusan Menteri Negara Lingkungan Hidup Nomor: KEP48/MENLH/11/1996 tentang Baku Tingkat Kebisingan. $\mathrm{KEP}=48 / \mathrm{MENLH} / 11 / 1996$ Indonesia; 1996.

12. Keputusan Menteri Tenaga Kerja Nomor: KEP-51/MEN/1999 tentang Nilai Ambang Batas Faktor Fisika di Tempat Kerja. 1999. 
13. Harrianto R. Buku Ajar Kesehatan Kerja. Hardiyanti EA, editor. Jakarta: Penerbit Buku Kedokteran EGC; 2008. 288 p.

14. Irianto K. Anatomi dan Fisiologi. Bandung: Alfabeta; 2012. 664 p.

15. Prof. Dr. Efiaty Arsyad Soepardi ST-K, Prof. Dr. Nurbaiti Iskandar ST-K, Prof. DR. Dr. Jenny bashiruddin ST-K, DR. Dr. Ratna Dwi Restuti ST-K, editors. Buku Ajar Ilmu Kesehatan Telinga Hidung Tenggorok Kepala \& Leher Edisi Ketujuh. Ketujuh. Fakultas Kedokteran Universitas Indonesia;

16. Anizar. Teknik Keselamatan dan Kesehatan Kerja di Industri. Pertama. Yogyakarta: Graha Ilmu; 2009. 190 p.

17. Salawati L. Noise-Induced Hearing Loss. J Kedokt Syiah Kuala. 2013;13(1):45-9.

18. Yadnya IWP, Putra NA, Aryanta IWR. Tingkat Kebisingan dan Tajam Dengar Petugas Ground Handling di Bandara Ngurah Rai Bali. Ecotropchic [Internet]. 4(2):97-100. Available from: http://download.portalgaruda.org/ article.php? article $=16263 \& \mathrm{val}=9$ 90

19. Mayasari D, Khairunnisa R. Pencegahan Noise Induced Hearing Loss pada Pekerja Akibat Kebisingan. J Agromed Unila. 2017;4(2):354-60.

20. Peraturan Menteri Tenaga Kerja dan Transmigrasi Republik Indonesia Nomor PER.08/MEN/VII/2010 tentang Alat Pelindung Diri. Indonesia; 2010.

21. Safetysign.co.id. Pemakaian Ear Plug degan Benar.
22. Sugiyono PD. Metode Penelitian Kuantitatif, Kualitatif dan R\&D. Bandung: Alfabeta; 2016. 334 p.

23. Siddiqui IA, Siddiqui RA. The Effect of Excessive Noise Exposure on The Hearing Thresholds of Aviation Workers in Karachi. Pak J Med Sci. 2008;24(4):525-30.

24. Joneri A. Pengaruh Faktor-Faktor Paparan Bising Mesin Pesawat Terbang Terhadap Gangguan Kemampuan Pendengaran pada Karyawan yang Bekerja di Apron Bandara Supadio Pontianak pada Bulan Januari 2011. Universitas Tanjungpura Pontianak; 2013.

25. Pratignyowati. Survey Penurunan Kemampuan Pendengaran karena KKepaparan Bising di PT (Persero) Angkasa Pura II Bandara Sukarno Hatta Tahun 2004. Universitas Indonesia; 2004.

26. Suprasetyo DJPU. Peraturan Direktur Jenderal Perhubungan Udara Nomor: KP 39 Tahun 2014 tentang Standar Teknis dan Operasi Peraturan Keselamatan Penerbangan Sipil - Bagian 139 (Manual of Standard CASR Part 139) VoluMe I Bandar Udara (Aerodromes). 2015.

27. Bogoch II, House RA, Kudla I. Perceptions About Hearing Protection and Noise Induced Hearing Loss of Attendees of Rock Concerts. Can J Public Heal. 2005;96(1):69-72.

28. Hammer MS, Swinburn TK, Neitzel RL. Environmental Noise Pollution in the United States: Developing an Effective Public Health Response. Environ Heal Perspect. 2014;122(2):115-9. 